\title{
REAKTIVASI PARADIGMA ISLAM WASATHIYYAH DI PERGURUAN TINGGI BERDASAR KONSULTASI TINGKAT TINGGI ULAMA DUNIA 2018
}

\author{
${ }^{1}$ Uswatun Hasanah, ${ }^{2}$ Akhmad Shunhaji, ${ }^{3}$ Saifuddin Zuhri \\ ${ }^{1}$ Institut PTIQ Jakarta \\ Email : uswahh1981@gmail.com \\ ${ }^{2}$ Institut PTIQ Jakarta \\ Email : akhmadshunhaji@ptiq.ac.id \\ ${ }^{3}$ Institut PTIQ Jakarta \\ Email: dzuhrie7393@gmail.com
}

\begin{abstract}
The paradigm of wasathiyyah Islamic is a form of Islamic understanding and practice, as well as an approach in contextualizing Islam in the midst of global civilization. The reactivation of the wasathiyyah Islamic paradigm was a response to various situations that attempted to divide the unity. This paradigm becomes important as a means of presenting the application of Islamic teachings that hold the principles of balance, justice and tolerance. This study aims to provide direction for Higher Education in developing the Islamic wasathiyyah paradigm. Through this research, the authors examined the wasathiyyah Islamic paradigm based on the Bogor Message which was produced at the 2018 World Ulama High Level Consultation (Summit) in Bogor. Bogor's message includes efforts to restore the Islamic wasathiyyah perspective as the center of Islamic teachings, both individually and collectively. One of the interesting messages to study is the commitment to reactivate the wasathiyyah Islamic perspective as a central Islamic teaching which includes seven main values, namely: tawassuth, i tidâl, tasâmuh, syûrâ, islah, qudwah, and muwâthanah. This study uses a qualitative approach with a literature study method. The result shows the reactivation of the wasathiyyah Islamic paradigm in higher education, can be developed through the cultivation of the seven main values of wasathiyyah Islam as contained in the Bogor Message.
\end{abstract}

Keywords : The Paradigm of Wasathiyyah Islamic, Higher Education, Ulama High Level Consultation. 
Abstrak : Paradigma Islam wasathiyah merupakan suatu corak pemahaman dan praktek Islam, serta suatu pendekatan dalam mengontekstualisasi Islam di tengah peradaban global. Pengaktifan kembali paradigma Islam wasathiyyah ini merupakan respon atas berbagai situasi yang berusaha memecah belah persatuan. Paradigma ini menjadi penting sebagai salah satu sarana untuk menghadirkan penerapan ajaran Islam yang memegang prinsip keseimbangan, keadilan dan toleransi. Penelitian ini bertujuan untuk memberikan arah bagi Perguruan Tinggi dalam mengembangkan paradigma Islam wasathiyyah. Melalui penelitian ini penulis mengkaji paradigma Islam wasathiyyah berdasarkan Pesan Bogor yang dihasilkan pada Konsultasi Tingkat Tinggi (KTT) Ulama Dunia 2018 di Bogor. Pesan Bogor mencakup upaya mengembalikan cara pandang Islam wasathiyyah sebagai pusat ajaran Islam, baik secara individu dan kolektif. Salah satu pesan yang menarik untuk dikaji adalah komitmen untuk mengaktifkan kembali cara pandang Islam wasathiyyah sebagai ajaran Islam pusat yang meliputi tujuh nilai utama, yakni: tawassuth, i’tidâl, tasâmuh, syûrâ, islah, qudwah, dan muwâthanah. Penelitian ini menggunakan pendekatan kualitatif dengan metode studi kepustakaan. Hasil penelitian menunjukkan pengaktifan kembali paradigma Islam wasathiyyah di perguruan tinggi, dapat dikembangkan melalui tujuh nilai utama Islam wasathiyyah sebagaimana termaktub dalam Pesan Bogor.

Kata Kunci : Paradigma Islam Wasathiyyah, Perguruan Tinggi, Konsultasi Tingkat Tinggi Ulama. 


\section{PENDAHULUAN}

Indonesia merupakan sebuah bangsa yang besar, sebagai negara terluas di Asia Tenggara (Ananda, 2015: 1) serta memiliki lebih dari 264,16 juta penduduk yang multi suku dan agama (BPS, 2018:7). Perhatian serius perlu diberikan pada kemajemukan agama di Indonesia karena berpotensi memicu konflik, bahkan dapat memunculkan ancaman perpecahan bangsa (Nuh, 2014: 3). Keberagaman perbedaan suku dan agama harus dikelola dengan benar agar memberikan pengaruh positif dalam membangun masyarakat Indonesia (Sastradiharja, 2011:4).

Dalam masyarakat yang sangat majemuk maka umat Islam sebagai umat mayoritas dapat menampilkan Islam rahmatan dan wasathan dengan tampil sebagai kekuatan perekat sekaligus menjadi pelindung kebhinnekaan (Usman, 2015: 1). Pemahaman Islam wasathiyyah ini penting karena pemahaman Islam yang wasath menjadi salah satu sarana untuk menghadirkan penerapan ajaran Islam yang memegang prinsip keseimbangan, keadilan dan toleransi.

Menurut Kepala Badan Intelijen Negara (BIN) Budi Gunawan, 39 persen mahasiswa di Indonesia sudah terpapar paham radikal. Dalam riset yang dilakukan BIN tahun 2017 itu, terdapat tiga universitas yang menjadi perhatian khusus karena menjadi basis penyebaran paham radikal tersebut, meskipun tidak disebut nama universitas yang dimaksud tersebut (Mazrieva, 2018). Berdasarkan penelitian tersebut, diketahui peningkatan paham konservatif keagamaan. Penelitian menunjukkan data 24 persen mahasiswa dan 23,3 persen pelajar SMA setuju dengan jihad demi tegaknya negara Islam.

Sementara data Badan Nasional Penanggulangan Terorisme (BNPT) menyebutkan, pelaku teroris terbesar berpendidikan SMA yakni 63,3 persen, kemudian disusul perguruan tinggi 16,4 persen, SMP 10,9 persen, tidak lulus perguruan tinggi 5,5 persen, dan SD 3,6 persen (Rozie, 2017). Data menunjukkan bahwa pelaku tindakan terorisme yang berpendidikan perguruan tinggi berada para peringkat kedua, sebesar 16,4 persen. Sedangkan berdasarkan umur pelaku terorisme terbanyak adalah usia 21-30 tahun yaitu sebesar 47,3 persen. Pelaku terorisme di bawah usia 21 tahun sebesar 11,8 persen. Hal ini menunjukan bahwa perguruan tinggi perlu mendapatkan perhatian khusus, karena usia mahasiswa D1, D3 dan S1 pada umumnya berkisar pada tentang usia 17 sampai 23 tahun. Pelaku tindakan teroris terbesar dalam data BNPT justru didominasi oleh pelaku berpendidikan menengah atas, menunjukkan bahwa nilai-nilai radikalisme sangat rentan bagi anak usia muda dan memiliki keterbatasan dalam memahami ajaran Islam yang nilai-nilainya apabila dipahami secara menyeluruh, jauh dari unsur terorisme dan radikalisme.

Dengan temuan atas berbagai problem pendidikan di atas, fakta yang sekarang dapat diamati adalah pendidikan tinggi di Indonesia masih belum banyak memberikan perhatian akan hal itu. Padahal problem tersebut harus mendapatkan perhatian yang besar karena berkaitan dengan pembentukan peradaban masyarakat yang kokoh. Sehingga pengaktifan kembali pemahaman Islam wasathiyyah di perguruan tinggi perlu mendapatkan perhatian secara sungguh-sungguh dari semua pihak yang terkait, baik itu dari pihak civitas perguruan tinggi maupun dari aparat pemerintah (Abdussalam dkk., 2018: 2). Maka dalam pandangan penulis perlu adanya penelitian terkait pengaktifan kembali nilai-nilai Islam wasathiyyah.

Berbagai penelitian tentang Islam wasathiyyah telah dihadirkan dalam wacana keilmuan kita, akan tetapi masih sangat jarang ditemukan kajian yang terperinci terkait Pemahaman Islam wasathiyyah mengenai berbasis Konsultasi Tingkat Tinggi Ulama (KTT) yang diselenggarakan pada 1- 3 Mei 2018 di Bogor. KTT Ulama tersebut dihadiri 100 peserta yang terdiri dari ulama dan cendekiawan Muslim dari berbagai belahan dunia (Muhyiddin, 2018). Menurut penulis, hasil KTT Ulama Dunia yang termaktub dalam Pesan Bogor ini perlu dikaji lebih mendalam memberikan makna yang lebih komprehensif tentang pemahaman Islam wasathiyyah. Salah satu pesan yang menarik untuk dikaji adalah komitmen untuk mengaktifkan 
kembali cara pandang Islam wasathiyyah sebagai ajaran Islam pusat yang meliputi tujuh nilai utama, yakni: tawassuth, ìtidâl, tasâmuh, syûrâ, islah, qudwah, dan muwâthanah.

Penelitian ini merupakan penelitian kualitatif dengan jenis penelitian yakni penelitian kepustakaan (Library Research). Adapun metode analisis data yang penulis gunakan dalam penelitian ini adalah metode Content Analysis. Metode Content Analysis merupakan metode yang digunakan untuk mengetahui karakteristik isi dan menarik inferensi dari isi yang dilakukan secara obyektif dan sistematis (Eriyanto, 2015: 15).

\section{PEMBAHASAN}

\section{Paradigma Islam Wasathiyyah}

Dalam pembahasan paradigma Islam wasathiyyah, perlu digarisbawahi terlebih dahulu, bahwa Islam itu sendiri memiliki makna wasathiyyah. Wasath dalam pandangan dan keyakinan, wasath pemikiran dan perasaan, wasath dalam keterikatan-keterikatannya. (Qutb, 2000: 100).

Wasathiyyah bukan merupakan satu mazhab dalam Islam dan bukan juga aliran baru. Akan tetapi wasathiyyah merupakan salah satu ciri utama ajaran Islam dan karena itu tidak tepat apabila dinisbatkan dengan satu kelompok Islam dengan mengabaikan kelompok lain. Bisa jadi dalam penerapannya, satu kelompok memiliki cara yang berbeda dengan kelompok lain untuk menyikapi masalah yang sama dalam suatu waktu, perbedaan itu tetap dapat diterima selama masih dapat ditampung dalam kandungan makna Islam wasathiyyah (Shihab, 2019: 38).

Islam wasathiyyah berasal dari dua kata, yaitu Islam dan wasathiyyah. Islam secara etimologi berasal dari akar kata salima yang berarti selamat, damai, sejahtera, lalu muncul kata aslama yang artinya menyelamatkan, mendamaikan dan mensejahterakan. Kata aslama juga berarti tunduk, menyerah dan patuh (Munawwir, 1997: 654). Islam merupakan agama yang meyakini syariat yang dibawa oleh para Rasul dan dibina atas dasar nilai ketauhidan (AlMahallî dan al-Suyûthî, t.th: 52). Inti ajaran Islam yang dibawa oleh para nabi ini mulai dari Nabi Adam a.s. hingga Nabi Muhammad saw. adalah satu, yaitu tauhid. Jadi Islam adalah kepatuhan dan penyerahan diri semata-mata kepada Allah mengikuti ajaran yang dibawa oleh para Nabi dengan Nabi Muhammad saw. sebagai nabi terakhir, untuk menjadi petunjuk bagi manusia dalam kehidupannya.

Menurut al-Râghib al-Ashfahâni (t.th.: 688) wasath adalah pertengahan sesuatu yang mempunyai 2 ujung, persis di tengah-tengahnya. Al-wasath terkadang digunakan untuk menunjukkan sesuatu yang terletak pada dua sikap yang tercela. Dalam al-Mu'jâm Wasîth dinyatakan wasath adalah apa yang terletak di antara dua ujung dan dia adalah bagian darinya, dapat juga berarti pertengahan dari segala sesuatu. Kata wasath juga berarti adil dan baik (Shihab, 2019: 2).

Menurut Wahbah az-Zuhaili (2011: 64), wasathiyyah adalah pertengahan di antara dua perkara yaitu tidak terlalu keras dan tidak terlalu permisif, tidak melewati batas (ekstrem) dan tidak mengabaikan, tidak berlebihan serta tidak fanatik dan tidak menyepelekan, keterhubungan antara materi atau substansi dengan esensi dalam perundang-undangannya, menghendaki keseimbangan serta mengimplementasikannya pada setiap urusan.

Dalam Islam konteks uraian tentang Islam wasathiyyah, para pakar sering merujuk pada kitab suci Al-Qur'an Surat Al-Baqarah/2: 143 yang mencantumkan kata ummatan wasathan. Menurut Asy-Sya'râwî (1991: 22) ayat ini menerangkan bahwa Allah SWT memberikan karunia kepada kita dengan menjadikan kita sebagai ummat wasathan. Pengertian al-wasath yaitu sesuatu yang terletak di antara dua ujung. Yang dimaksud dengan ummatan wasathan adalah wasath dalam iman dan aqidah. Di satu sisi ada kelompok yang mengingkari adanya satu Ilah yang haq. Di sisi lain terdapat kelompok yang menyembah banyak Tuhan. Kedua sisi ini tidak benar, adapun kaum muslimin meyakini bahwa Tidak ada Ilah kecuali 
Allah tidak ada sekutu bagi-Nya. Sedangkan Tafsir Jalâlain (Al-Mahallî dan al-Suyûthî, t.th: 29) menerangkan makna dari kata wasathan adalah umat yang adil dan pilihan.

Quraish Shihab (2019: 43) memberikan kesimpulan dari uraian para pakar bahwa wasathiyyah adalah keseimbangan dalam segala permasalahan hidup duniawi dan ukhrawi, yang selalu disertai upaya menyesuaikan diri dengan situasi yang dhadapi berdasarkan petunjuk agama dan kondisi obyektif yang sedang dialami.

Jadi paradigma Islam wasathiyyah merupakan suatu corak pemahaman dan pratek Islam, serta suatu pendekatan dalam mengontekstualisasi Islam di tengah peradaban global. Cara pandang bahwa agama Islam merupakan agama tauhid yang mengedepankan nilai-nilai keseimbangan, keadilan, toleransi dan kebijaksanaan sehingga mampu menjadi rahmat bagi seluruh alam.

\section{a. Tujuh Nilai Utama Islam Wasathiyyah}

Tujuh nilai utama Islam wasathiyyah berdasar Konsultasi Tingkat Tinggi (KTT) Ulama Dunia yang diselenggarakan pada 1-3 Mei 2018 di Bogor yang termaktub dalam Pesan Bogor yaitu: tawassuth, i tidâl, tasâmuh, syûrâ, islah, qudwah, dan muwâthanah.

\section{b. Tawassuth}

Dalam kehidupan sehari-hari, tawassuth diwujudkan pada sikap yang seimbang antara pikiran dan tindakan, tidak gegabah dalam mengambil keputusan, apalagi menghakimi. Tawassuth melekat sangat kuat pada nilai-nilai Islam di dunia sebagai pola pikir dalam kehidupan beragama, termasuk juga di Indonesia.

Menurut Abbas Mahmud Al-Aqqad (Shihab, 2019: 29) kata tawassuth yang merupakan sikap pertengahan tidak boleh dipahami secara matematis. Pandangan tentang posisi tengah dengan menetapkan tolok ukur matematis seperti yang selama ini dipahami sebagian orang atau yang mengabaikan nilai ruhani dan faktor-faktor psikologis tidaklah tepat.

Sikap tawassuth mencakup seluruh aspek kehidupan, baik dalam pemikiran maupun dalam pergerakan. Hal ini tercermin dalam keyakinan yang sesuai dengan fitrah dan ibadah yang mendorong pada upaya pemakmuran dunia. Dalam hal pemikiran, melahirkan konsep untuk ikut berkontribusi melalui risalah agama untuk memperbaiki memperbaiki kehidupan masyarakat, tatanan politik negara, kebangkitan bangsa dan reformasi kehidupan. Tawassuth dalam pergerakan dapat dilihat dari sikap dan perilaku pribadi muslim yang proporsional dalam menghadapi perbedaan dalam masyarakat. Selain itu juga dapat diamati dari penggunaan prinsip-prinsip sesuai ajaran Islam wasathiyah sebagai landasan untuk mengambil, menerima atau melakukan seleksi dalam interaksi dengan kebudayaan lain (Nur \& Lubis, 2015: 212-213). Dalam kehidupan berbangsa dan bernegara, sikap tawassuth tercermin dari disepakatinya Pancasila sebagai dasar negara oleh para founding fathers.

\section{c. I tidâl}

Dalam pesan Bogor (Rahmawaty, 2018), I tidâl didefinisikan sebagai perilaku proporsional dan adil dengan disertai tanggung jawab. Secara etimologi "adil" ( $a l$ - ' $a d l$ ) berarti tidak memihak atau tidak berat sebelah. Adil juga bermakna menyamakan sesuatu dengan yang lain. Istilah lain dari al- 'adl adalah al-qist, al-misl; yang berarti sama dengan bagian atau semisal (Dahlan, 1996: 25).

Keadilan dalam Islam paling tidak mencakup beberapa makna yaitu: keadilan dalam arti sama atau persamaan; keadilan dalam arti proporsional (seimbang); keadilan dalam arti memberikan hak kepada pemiliknya (Dery, 2002: 50). Keadilan yang berarti kesamaan memberi kesan adanya dua pihak atau lebih, karena apabila hanya satu pihak saja maka tidak akan terjadi adanya persamaan (Shihab, 1996: 111). 
Keadilan dalam arti seimbang identik dengan proporsional atau kesesuaian. Keseimbangan tidak mengharuskan persamaan kadar supaya seimbang, bisa jadi salah satu bagian berukuran besar atau kecil, sesuai fungsi yang diharapkan darinya (Shihab, 1996:118). Makna keadilan selanjutnya yaitu keadilan dalam arti perhatian terhadap hak-hak individu serta pemberian hak-hak kepada para pemiliknya. Lawan keadilan dalam definisi ini adalah kezaliman.

Muthahhari (1995: 35) juga mengemukakan bahwa konsep adil dikenal dalam empat hal yaitu: adil bermakna keseimbangan; adil bermakna pemeliharaan persamaan ketika hak memilikinya sama, sebab keadilan mewajibkan persamaan seperti itu dan mengharuskanya; adil dalam makna pemeliharaan hak-hak individu; dan adil dalam makna memelihara hak atas berlanjutnya eksistensi.

Al-Mahallî dan al-Suyûthî (t.th: 137) menerangkan bahwa pada Al-Qur'an surat Al-Maidah/5:8 Allah memerintahkan kepada orang-orang yang beriman, hendaknya selalu menegakkan kebenaran, menjadi saksi yang adil karena Allah, dan tidak boleh menjadikan kebencian kepada sesuatu kaum yakni kepada orang-orang kafir sebagai alasan untuk berlaku tidak adil sehingga menganiaya mereka karena permusuhan mereka itu. Allah memerintahkan orang beriman berlaku adil baik terhadap lawan maupun terhadap kawan karena hal itu artinya keadilan itu lebih dekat kepada ketakwaan. Dan hendaknya bertakwa kepada Allah, sesungguhnya Allah Maha Mengetahui apa yang dikerjakan hamba-hamba-Nya sehingga seorang hamba akan menerima pembalasan amal dari Allah.

Ayat tersebut menunjukkan bahwa kebencian terhadap suatu kaum tidak boleh membuat seseorang untuk berlaku tidak adil. Hubungan muslim dan nonmuslim dalam hidup bernegara adalah hubungan kewarganegaraan yang dilukiskan oleh Nabi Muhammad SAW dalam piagam Madinah. Yaitu bahwa kaum nonmuslim memiliki hak yang sama dengan hak kaum muslimin, dan memiliki kewajiban yang sama sebagaimana kewajiban kaum muslimin (Ahmad, 2014: 18). Dapat dipahami bahwa perintah berlaku adil merupakan ajaran yang ditekankan dalam Islam, tidak ada diskrimisasi hukum dan di atas semua anggota masyarakatnya, hukum berlaku bagi semua warga negara.

\section{d. Tasâmuh}

Tasâmuh dapat ditanamkan kepada mahasiswa untuk mengakui dan menghormati perbedaan dalam semua aspek kehidupan. Ajaran Islam yang senantiasa memberi penekanan kepada umatnya agar terus bersikap toleransi kepada orang bukan Islam. Toleransi dalam Islam tidak asing lagi dan bahkan mengeksistensi sejak Islam itu ada. Persoalan mendasar dalam toleransi adalah implementasi dan komitmen untuk mempraktikkannya secara konsisten (Aslati, 2012: 52).

Toleransi beragama adalah sikap bersedia menerima keanekaragaman dan kebebasan agama yang dianut dan kepercayaan yang dihayati oleh pihak lain (Sudibjo, 1991: 384). Namun, hal yang perlu ditekankan pada mahasiswa adalah toleransi beragama menurut Islam bukanlah untuk saling melebur dalam keyakinan, bukan untuk saling bertukar keyakinan di antara kelompok-kelompok agama yang berbeda itu. Toleransi di sini adalah dalam pengertian interaksi sosial. Jadi, terdapat batas-batas bersama yang boleh dan tak boleh dilanggar.

Realitas adanya perbedaan pendapat di antara anggota masyarakat merupakan sunnatullah dan akan senantiasa terjadi perbedaan dalam masyarakat (Ali, 2007: 56). Oleh karena itulah perlu ditanamkan sikap toleransi pada mahasiswa. Pengakuan dan penghargaan terhadap adanya perbedaan ini merupakan nilai-nilai Islam wasathiyyah yang sangat penting. Pengakuan terhadap adanya keanekaragaman suku bangsa dan agama menjadi acuan dalam mewujudkan keharmonisan dalam kehidupan. 


\section{e. Syûrâ}

Nilai Syûrâ dapat ditanamkan kepada mahasiswa agar mampu yaitu menyelesaikan persoalan melalui jalan musyawarah untuk mencapai mufakat dengan prinsip menempatkan kemaslahatan sebagai acuan utamanya. Dalam musyawarah peserta dapat mengemukakan pendapat dengan saling merevisi antara mereka (alAshfahâni, t.th.: 270). Mahasiswa yang memahami Islam wasathiyyah dengan baik akan bersandar pada konsultasi dan menyelesaikan masalah melalui musyawarah untuk mencapai konsensus. Melalui musyawarah diharapkan akan diperoleh keputusan yang terbaik sehingga membawa kemaslahatan umat.

Musyawarah hendaknya dilakukan dalam berbagai urusan, baik yang ada dalil (maka musyawarah berkaitan dengan cara dan jalan melaksanakannya) maupun yang tidak ada dalil, musyawarah dilakukan secara ijtihâdiyyah berdasar atas kemaslahatan (Rasyid, 2018: 503).

Esensi musyawarah menunjukkan keutamaan yang manusiawi dan realitas persamaan kedudukan dan derajat manusia, kebebasan berpendapat dan hak kritik serta pengakuan terhadap kemanusiaan itu sendiri. Melalui musyawarah dapat ditemukan cara untuk mempersatukan golongan-golongan dengan berbagai atribut di tengah-tengah bergejolaknya masalah-masalah dalam masyarakat (Hanafi, 2013: 230).

Perbedaan pandangan dan pemikiran hendaknya tidak menghalangi seorang muslim untuk menjaga persaudaraan. Mempertahankan keyakinan, pendapat dan pandangan merupakan hak asasi manusia, namun bukan berarti harus ada permusuhan, pertikaian dan perpecahan (Al-Qadri, 2014:32). Musyawarah sangat penting, dan hendaknya dijadikan sebagai kebiasaan dalam mengambil keputusan untuk kepentingan bersama. Musyawarah dapat mewujudkan kesatuan bangsa, melatih kegiatan berpikir dan sebagai sarana menuju kepada kebenaran yang mengandung kebaikan dan keberkahan.

Adapun manfaat musyawarah banyak sekali, antara lain adalah sebagai berikut: melalui musyawarah, dapat diketahui kadar akal, pemahaman, kadar kecintaan, dan keikhlasan terhadap kemaslahatan umum; dapat menemukan solusi yang dianggap terbaik karena kemampuan akal manusia itu bertingkat-tingkat, dan jalan berfikirnya pun berbeda-beda; dalam musyawarah, akan tampak bersatunya hati untuk mensukseskan suatu upaya dan kesepakatan hati (Mukhid, 2016:24-25).

\section{f. Islah}

Islah adalah meniadakan setiap konflik dalam hubungan yang rusak antara individu dengan individu, antara kelompok sebagai akibat timbulnya pertikaian atau perselisihan, memutuskan hubungan persaudaraan (Fikri, 2016: 201). Makna islah dalam kajian hukum Islam adalah memperbaiki, mendamaikan dan menghilangkan sengketa atau kerusakan. Berusaha menciptakan perdamaian, membawa keharmonisan, mengajurkan orang untuk berdamai satu dengan yang lainnya, melakukan perbuatan yang baik (Dahlan, 1996:740). Dalam al-Qur'an surat al-Hujurat/49:10: dicantumkan kata islah yang menekankan tentang perlunya menjaga perdamaian dalam kehidupan.

Apabila dicermati secara sungguh-sungguh maka terdapat panduan dari Rasulullah (Ahmad, 2014: vii-viii) tentang persaudaraan baik dengan muslim maupun persaudaraan sebagai sesama umat manusia dengan umat agama lain. Manusia diciptakan oleh Allah SWT dan dijadikan khalifah di bumi ini memiliki tugas untuk memakmurkan bumi, dan bukan untuk menghancurkannya (Surasman, 2020: 97). Dalam menjalankan tugas dakwah, seorang muslim hendaknya menggunakan metode yang baik membawa kesejukan, tanpa diiringi dengan rasa kebencian dan permusuhan.

Sesungguhnya dakwah yang membawa perpecahan akan membawa pada kegagalan dan kerusakan, akan tetapi dakwah yang diajarkan Oleh Rasulullah SAW 
adalah dakwah yang membawa kesuksesan dan menghadirkan pertolongan. Ajaran perdamaian ini yang akan dilakukan oleh setiap hati yang bersedia mendengarkan petunjuk Nabi Muhammad dalam menyampaikan ajaran Islam pada Umat ini (Habib Umar, 2013:22).

Upaya menjaga islah merupakan penerapan pemahaman Islam wasathiyah dalam kehidupan berbangsa dan bernegara. Islah ini dapat diwujudkan dalam hubungan antar pribadi masyarakat maupun dalam hubungan sosial yang lebih besar. Salah satu perwujudan sikap perdamaian dan mencegah kerusakan ini adalah dalam bentuk menghindari kekerasan, tindakan anarkis dan tindakan terorisme. Dalam tahap berikutnya sikap islah bisa diwujudkan dalam hubungan sosial yang baik baik dengan sesama muslim maupun dengan kelompok agama lain.

Maka dalam hubungan kemasyarakatan, Al-Qur'an memerintahkan dan menganjurkan untuk bersedekah baik kepada muslim maupun nonmuslim apabila membutuhkan bantuan. Mengenai sedekah kepada nonmuslim ini, Ibnu Abbas meriwayatkan bahwa sebagian kaum muslimin memiliki keturunan dan kerabat dari Quraizhah dan An-Nadhir. Mereka menahan diri untuk bersedekah kepada kerabatnya tersebut dengan tujuan agar kerabatnya masuk Islam, kemudian turunlah Al-Qur'an surat al-Baqarah/2:272 (at-Thabari, t.th: 339).

Menurut Tafsir Muyassar, ayat tersebut menjelaskan bahwa bukanlah tugas Rasul untuk memberikan petunjuk kepada mereka agar menerima dan tunduk pada kebenaran, akan tetapi Allah memberikan hidayah petunjuk kepada siapa saja yang dikehendaki-Nya. Dan harta yang diinfakkan, manfaatnya akan kembali kepada yang berinfak, karena Allah tidak membutuhkannya. Orang-orang yang beriman dalam berinfak ikhlas semata-mata hanya karena Allah. Harta yang diinfakkan baik sedikit maupun banyak maka pahalanya akan diberikan secara penuh serta tidak akan dikurangi sedikitpun (Tim Ulama, 2009: 46).

Mengenai sebab turunnya ayat tersebut, Qatadah menuturkan bahwa sekelompok sahabat Nabi berkata "Bolehkah kita bersedekah kepada orang yang bukan penganut agama kita?" Lantas Allah menurunkan ayat Al-Qur'an ini (at-Thabari, t.th:588). Sehingga dapat dipahami bahwa Al-Qur'an memerintahkan dan menganjurkan bersedekah termasuk pada nonmuslim (Sirjani, 2015: 114).

Ayat ini menunjukkan bahwa Allah mengajarkan kepada kaum muslimin untuk memberikan bantuan kepada semua pihak yang membutuhkan pertolongan semata-mata mengharapkan ridho Allah. Tidak ada pamrih sama sekali. Bahkan juga dianjurkan memberikan pertolongan kepada pemeluk agama lain yang memerlukan uluran tangan dari kaum muslimin.

Walter Houston Clark, dalam bukunya Psychology of Religion, memberikan sejumlah pertanyaan untuk mengukur kematangan beragama seseorang. Dari pertanyaan yang disampaikan mengarah pada suatu kesimpulan bahwa semakin matang pemahaman keagamaan seseorang maka seharusnya semakin meyakini bahwa agama adalah sesuatu yang pokok, semakin sejuk kehidupannya, seseorang memiliki kematangan beragama tinggi bersedia melakukan instrospeksi diri, agama mampu memberikan makna dinamis, memberikan efek sosial, menunjukkan kerendahan hati dan melahirkan kreativitas (Buseri, 2015: 9).

Dari penjelasan tersebut dapat diambil suatu pemahaman bahwa semakin matang pemahaman keagamaan seseorang maka kecenderungan untuk berbuat kerusakan, anarkisme dan terorisme akan semakin rendah. Dan seseorang yang beriman dengan baik tidak akan berbuat kerusakan. Bahkan seorang yang beriman akan hadir dengan melakukan islah dalam bentuk terlibat dalam tindakan reformatif dan konstruktif untuk kebaikan bersama. 


\section{g. Qudwah}

Qudwah dalam pengertian ini adalah merintis inisiatif mulia dan memimpin untuk kesejahteraan manusia (Rahmawaty, 2018). Al-Qudwah atau al-qidwah secara bahasa berarti sesuatu yang layak untuk diikuti atau diteladani.(Ibnu Manzhur, t.th: 3556)

Muhammad Quthb berpandangan bahwa kebutuhan manusia terhadap figur dan model teladan dari manusia yang lain sangatlah dibutuhkan. Hal ini menjadi landasan bagi urgensitas metode keteladanan (Maya, 2017:14). Qudwah ini juga merupakan salah satu nilai utama Islam wasathiyyah. Secara teologis, Rasulullah saw. bukan hanya sebagai utusan Allah yang memberikan penjelasan terhadap segala ajaran yang terkandung dalam Al-Qur'an, tetapi rasul juga teladan (uswah hasanah) dalam segala aspeknya. Baik itu urusan 'aqa'id, ta'abbudi dan ta'ammuli (Tim Lajnah, 2010: 216).

Rasulullah juga telah mengajarkan dan memberikan contoh tentang kepemimpinan yang ideal. Rasulullah saw. merupakan figur pemimpin yang memberikan pengajaran luar biasa dalam mendidik umatnya. Sebagai pemimpin yang memberikan bimbingan, memberikan pengajaran, memberikan motivasi serta memberikan kesempatan pada para sahabatnya untuk berpartisipasi dalam menopang dakwah. Selain itu Rasulullah juga memberikan tugas pendelegasian untuk para sahabat dalam peran-peran yang strategis dalam dakwah.

Dalam upaya meletakkan dasar-dasar politik, ekonomi, dan sosial, berikut ini langkah-langkah yang dilakukan oleh Rasulullah: menjamin kebebasan beragama, menetapkan hukum-hukum privat, misalnya hukum keluarga kemudian menetapkan hukum masalah publik seperti interaksi sosial; membangun dasar-dasar sistem musyawarah, munculnya sistem baru dalam perdagangan, yaitu sistem dangang nonribawi yang melarang adanya eksploitasi, monopoli dan rentenir; dalam bidang kemasyarakatan dibuatlah dasar-dasar sistem sosial seperti ukhuwah (persaudaraan), musawah (persamaan), tasamuh (toleransi), musyawarah dan kerjasama (Al-Azizi, 2014: 45-46).

Rasulullah saw. melalui ajaran-ajaran beliau telah memberikan teladan yang nyata tentang perlunya merintis inisiatif mulia dan bahwa kepemimpinan yang beliau contohkan adalah kepemimpinan untuk membawa pada kesejahteraan manusia.

\section{h. Muwâthanah,}

Muwâthanah yaitu mengakui negara bangsa dan menghormati kewarganegaraan. Dalam konteks ini, muwâthanah adalah pengakuan terhadap Negara Kesatuan Republik Indonesia, pengakuan terhadap Pancasila sebagai dasar negara dan pengakuan terhadap kewarganegaran.

Menurut Akhmad Shunhaji, kemampuan beragama umat Islam dalam kehidupan berbangsa dan bernegara dapat dibagi menjadi empat macam. Pertama yaitu umat yang memahami pengetahuan agama dan mengamalkan pengetahuannya dalam kehidupan berbangsa dan bernegara. Kedua, umat yang memahami pengetahuan agama, tetapi tidak mengamalkan pengetahuan yang dimiliki dalam kehidupan berbangsa dan bernegara. Ketiga, umat yang tidak memahami pengetahuan agama tetapi merasa paham dengan ajaran agama. Kelompok ketiga ini mengamalkan pengetahuan semunya dalam kehidupan berbangsa dan bernegara. Keempat yaitu umat yang tidak memahami pengetahuan agama dan tidak bisa mengamalkan ajaran agama dalam kehidupan berbangsa dan bernegara (Shunhaji, 2017: 109).

Sehingga dalam kehidupan berbagsa dan bernegara akan kita dapati berbagai macam pemikiran dan sikap kebangsaan. Islam mengakui keragaman umat manusia sebagaimana termaktub dalam Al-Qur'an. Dalam Al-Qur'an surat al-Hujurat/49:13. Dalam Tafsir Ibnu Katsir dijelaskan bahwa Allah Swt. menyampaikan kepada manusia 
bahwa Allah telah menciptakan manusia dari diri yang satu, darinya Allah menciptakan istrinya, yaitu Adam dan Hawa, kemudian Allah menjadikan mereka sebagai manusia yang berbangsa-bangsa. Pengertian bangsa dalam bahasa Arab adalah sya'bun yang memiliki arti lebih besar daripada kabilah. Demikian itu agar saling mengenal di antara sesamanya, masing-masing dinisbatkan kepada kabilah (suku atau bangsa) nya Ibnu Katsir, 1974: 1751).

Sejarah telah membuktikan bahwa Rasulullah SAW telah menginisiasi lahirnya Piagam Madinah pada tahun $1 \mathrm{H}(622 \mathrm{M})$ sebagai pertanda lahirnya konstitusi tertulis pertama di dunia (Ahmad, 2014: xii). Salah satu pokok ketentuan dalam piagam Madinah adalah persatuan di bawah payung perdamaian, serta kebebasan memeluk agama masing-masing baik itu Islam, Nasrani, Yahudi maupun seluruh masyarakat Madinah yang lain (Al-Azizi, 2014: 44).

Abdul Qadir Audah (2014: 167), menerangkan prinsip-prinsip masyarakat Islam dalam bukunya Al-Islam wa Audha'una Al-Qanuniyah sebagai berikut: persamaan yang merata di antara segenap manusia, baik perorangan maupun kumpulan, di antara berbagai bangsa, ataupun antara yang memerintah dengan yang diperintah; penerapan keadilan yang mutlak di segala bidang; kemerdekaan dalam arti yang luas, baik spiritual maupun material; persaudaraan yang mendalam karena dorongan semangat keagamaan yang tulus.

Prinsip selanjutnya adalah persatuan yang berdasarkan persaudaraan; saling membantu dan membela dari segala gangguan; memelihara kesopanan dan kehormatan; menjunjung tinggi akhlak mulia; pengakuan bahwa segala ciptaan Allah baik di darat, laut maupun udara adalah hak bersama; memelihara kesejahteraan sosial, menyayangi sesama makluk dan melakukan kebajikan; serta memegang teguh prinsip musyawarah.

\section{Reaktivasi Islam Wasathiyyah Di Perguruan Tinggi}

Untuk mengaktifkan kembali paradigma Islam wasathiyyah di Perguruan Tinggi perlu dilakukan berbagai upaya. Upaya tersebut antara lain adalah: menekankan tujuan pembelajaran agama sebagai pengamalan bukan sebagai pengetahuan semata. mengembangkan materi pembelajaran ke arah pengetahuan metakognitif, menggunakan pendekatan multiperspektif yang memungkinkan terjadinya dialektika pemahaman dan pemikiran keagamaan. Aam Abdussalam (2018:2). Pendidik perlu mengajarkan multiperspektif kepada mahasiswa agar mampu menghargai cara pandang orang lain yang berbeda dengannya. Kemampuan ini penting agar mampu bersikap lebih bijaksana dalam menyikapi keragaman dalam kehidupan sosial keagamaan.

Pengaktifan kembali tujuh nilai utama Islam Wasathiyyah di perguruan Tinggi dapat dilakukan peningkatan pemahaman terkait tawassuth, ìtidâl, tasâmuh, syûrâ, islah, qudwah, dan muwâthanah. Menurut Darwis Hude (2018:25), kebermaknaan suatu pendidikan agama Islam akan dilihat pada konsistensi dalam pengamalan, bukan pada seberapa banyak pengetahuan yang dimiliki oleh siswa. Model materi pendidikan agama Islam yang ideal adalah sentrifugal dengan mengetahui dan mengamalkan hal-hal mendasar kemudian dari waktu ke waktu berkembang menjadi pengetahuan luas yang terus diamalkan secara konsisten.

\section{a. Tawassuth}

Dalam kehidupan sehari-hari, tawassuth ditanamkan dengan mengajarkan keseimbangan antara pikiran dan tindakan, tidak gegabah dalam mengambil keputusan, apalagi menghakimi. Perlu juga ditanamkan bahwa tawassuth merupakan sikap pertengahan tidak boleh dipahami secara matematis. Pandangan tentang posisi tengah dengan menetapkan tolok ukur matematis seperti yang selama ini dipahami sebagian orang atau yang mengabaikan nilai ruhani dan faktor-faktor psikologis tidaklah tepat.

Sikap tawassuth dapat tercermin dalam keyakinan yang sesuai dengan fitrah dan ibadah yang mendorong pada upaya pemakmuran dunia. Dalam hal pemikiran, 
sikap ini melahirkan konsep untuk ikut berkontribusi melalui risalah agama untuk memperbaiki memperbaiki kehidupan masyarakat, tatanan politik negara, kebangkitan bangsa dan reformasi kehidupan. Pemahaman yang baik terhadap konsep tawassuth dapat membantu mahasiswa untuk dapat menggunakan prinsip-prinsip sesuai ajaran Islam wasathiyah untuk mengambil, menerima atau melakukan seleksi dalam interaksi dengan kebudayaan lain (Nur \& Lubis, 2015: 212-213).

b. I tidâl

Pemahaman makna keadilan dapat ditanamkan kepada para mahasiswa dengan memberikan keteladanan terkait perilaku proporsional dan adil dengan disertai tanggung jawab. Selain itu perlu ditanamkan bahwa kebencian terhadap suatu kaum tidak boleh membuat seseorang untuk berlaku tidak adil. Hubungan muslim dan nonmuslim dalam hidup bernegara adalah hubungan kewarganegaraan yang dilukiskan oleh Nabi Muhammad SAW dalam piagam Madinah, yaitu bahwa kaum nonmuslim memiliki hak yang sama dengan hak kaum muslimin, dan memiliki kewajiban yang sama sebagaimana kewajiban kaum muslimin (Ahmad, 2014: 18).

Mahasiswa perlu diperkenalkan empat konsep tentang makna yaitu: adil bermakna keseimbangan; adil bermakna pemeliharaan persamaan ketika hak memilikinya sama, sebab keadilan mewajibkan persamaan seperti itu dan mengharuskanya; adil dalam makna pemeliharaan hak-hak individu; dan adil dalam makna memelihara hak atas berlanjutnya eksistensi. (Muthahhari, 1995: 35).

c. Tasâmuh

Tasâmuh dapat ditanamkan kepada mahasiswa untuk mengakui dan menghormati perbedaan dalam semua aspek kehidupan. Ajaran Islam yang senantiasa memberi penekanan kepada umatnya agar terus bersikap toleransi kepada orang bukan Islam. Toleransi dalam Islam tidak asing lagi dan bahkan mengeksistensi sejak Islam itu ada. Persoalan mendasar dalam toleransi adalah implementasi dan komitmen untuk mempraktikkannya secara konsisten (Aslati, 2012: 52).

Toleransi beragama adalah sikap bersedia menerima keanekaragaman dan kebebasan agama yang dianut dan kepercayaan yang dihayati oleh pihak lain (Sudibjo, 1991: 384). Namun, hal yang perlu ditekankan pada mahasiswa adalah toleransi beragama menurut Islam bukanlah untuk saling melebur dalam keyakinan, bukan untuk saling bertukar keyakinan di antara kelompok-kelompok agama yang berbeda itu. Toleransi di sini adalah dalam pengertian interaksi sosial. Jadi, terdapat batas-batas bersama yang boleh dan tak boleh dilanggar.

Keragaman merupakan sunnatullah dan akan senantiasa terjadi perbedaan dalam masyarakat. Oleh karena itulah perlu ditanamkan sikap toleransi pada mahasiswa. Pengakuan dan penghargaan terhadap adanya perbedaan ini merupakan nilai-nilai Islam wasathiyyah yang sangat penting. Pengakuan terhadap adanya keanekaragaman suku bangsa dan agama menjadi acuan dalam mewujudkan keharmonisan dalam kehidupan.

d. Syûrâ

Nilai Syûrâ dapat ditanamkan kepada mahasiswa agar mampu yaitu menyelesaikan persoalan melalui jalan musyawarah untuk mencapai mufakat dengan prinsip menempatkan kemaslahatan sebagai acuan utamanya. Dalam musyawarah peserta dapat mengemukakan pendapat dengan saling merevisi antara mereka (alAshfahâni, t.th.: 270). Mahasiswa yang memahami Islam wasathiyyah dengan baik akan bersandar pada konsultasi dan menyelesaikan masalah melalui musyawarah untuk mencapai konsensus. Melalui musyawarah diharapkan akan diperoleh keputusan yang terbaik sehingga membawa kemaslahatan umat.

Hal yang utama dalam menanamkan pemahaman ini adalah bahwa perbedaan pandangan dan pemikiran hendaknya tidak menghalangi seorang muslim untuk menjaga 
persaudaraan. Perlu ditekankan juga bahwa mempertahankan keyakinan, pendapat dan pandangan merupakan hak asasi manusia, namun bukan berarti harus ada permusuhan, pertikaian dan perpecahan (Al-Qadri, 2014:32).

e. Islah

Pemahaman terhadap urgensi sikap islah ini dapat ditanamkan pada mahasiswa dengan melakukan hubungan sosial yang baik antar pribadi masyarakat maupun dalam hubungan sosial yang lebih besar. Salah satu perwujudan sikap perdamaian dan mencegah kerusakan ini adalah dalam bentuk menghindari kekerasan, tindakan anarkis dan tindakan terorisme. Sikap islah bisa diwujudkan dalam hubungan sosial yang baik baik dengan sesama muslim maupun dengan kelompok agama lain.

Pesan-pesan dakwah dan materi agama harus dilakukan dengan bijaksana. Menghindari metode dakwah yang membawa perpecahan. Salah satu upaya yang dapat dilakukan dalam menanamkan konsep islah adalah dengan memberikan pemahaman materi keagamaan secara utuh dan matang. Semakin matang pemahaman keagamaan mahasiswa maka kecenderungan untuk berbuat kerusakan, anarkisme dan terorisme akan semakin rendah. Dan seseorang yang beriman dengan baik tidak akan berbuat kerusakan. Bahkan seorang yang beriman akan hadir dengan melakukan islah dalam bentuk terlibat dalam tindakan reformatif dan konstruktif untuk kebaikan bersama.

\section{f. Qudwah}

Untuk menanamkan qudwah pada mahasiswa, para pendidik dapat mengikuti teladan Rasulullah saw. dalam hal kepemimpinan. Ajaran-ajaran beliau telah memberikan teladan yang nyata tentang perlunya merintis inisiatif mulia dan bahwa kepemimpinan yang beliau contohkan adalah kepemimpinan untuk membawa pada kesejahteraan manusia. Kajian ilmiah tentang kepemimpinan Rasulullah Saw. dan latihan kepemimpinan dapat diberikan sebagai salah satu upaya melahirkan sikap kepemimpinan yang ideal sesuai ajaran Islam.

\section{g. Muwâthanah,}

Muwâthanah merupakan sikap mengakui negara bangsa dan menghormati kewarganegaraan. Dalam kehidupan kampus, pemahaman tentang muwâthanah merupakan hal yang sangat krusial. Maka perlu diberikan pemahaman tentang pandangan Islam terhadap nasionalisme. Dalam hal ini adalah pengakuan terhadap Negara Kesatuan Republik Indonesia, pengakuan terhadap Pancasila sebagai dasar negara dan pengakuan terhadap kewarganegaran. Perlu dibentuk generasi muda yang memahami pengetahuan agama secara utuh dan mengamalkan pengetahuannya dalam kehidupan berbangsa dan bernegara.

\section{KESIMPULAN}

Pendidikan Tinggi perlu memperkuat pemahaman Islam wasahiyyah. Nilai-nilai utama Islam wasathiyyah yang termaktub dalam Pesan Bogor dapat dijadikan sebagai dasar pengaktifan kembali paradigma Islam wasathiyyah. Cara pandang Islam wasathiyyah sebagai ajaran Islam meliputi tujuh nilai utama, yakni: tawassuth, ìtidâl, tasâmuh, syûrâ, islah, qudwah, dan muwâthanah. Sebagai acuan dasar tentu hasil penelitian ini dapat dikembangkan dalam langkah-langkah aplikatif di ranah kebijakan dan dalam perencanaan pengembangan pendidikan terutama di perguruan tinggi.

\section{DAFTAR PUSTAKA}

Abdussalam, Aam, et al. (2018). Panduan Pelaksanaan Bimbingan Teknis Dosen MKWU Pendidikan Agama Islam. Bekasi: Kementerian Riset, Teknologi, dan Pendidikan Tinggi. 
${ }^{1}$ Uswatun Hasanah, ${ }^{2}$ Aאל̧mad Shunhaji, ${ }^{3}$ Saifuddin Zuhri

Afrizal Nur \& Mukhlis Lubis. (2015). Konsep Wasathiyah dalam Al-Qur'an. An-Nur, 4(2), 212-213.

Ahmad, Zainal Abidin. (2014). Piagam Madinah Konstitusi Tertulis Pertama di Dunia. Jakarta: Pustaka Al-Kautsar.

al-Ashfahâni, al-Râghib. (t,th.), al-Mufradât fî Gharîb al-Qur'ân, Makkah: Dâr Musthofâ al Bâz.

Al-Azizi, Abdul Syukur. (2014). Kitab Sejarah Peradaban Islam Terlengkap. Jakarta: Saufa.

Ali, Zainuddin. 2007. Pendidikan Agama Islam, Jakarta: PT Bumi Aksara.

Alpizar. (2015). Toleransi Terhadap Kebebasan Beragama Di Indonesia (Perspektif Islam). Toleransi, 7(2), 132-153.

Al-Qadri, Al-Hamid Jakfar. (2014). Bijak Menyikapi Perbedaan Pendapat: Telaah atas Pemikiran Al-Habib Umar bin Hafizh dalam Membina Ukhuwah dan Membangun Dialog. Jakarta: Mizan.

Ananda, Aris, et al. (2015). Demography of Indonesia's Ethnicity. Singapore: Institute of Southeast Asian Studies.

Aslati. 2012. Toleransi Beragama Dalam Perspektif Islam.Toleransi, 4(1), 52-58.

Ath-Thabari. (t.th.). Jami' Al-Bayan fi Ta'wil Ay Al-Qur'an, Cairo: Maktabah Ibn Taimiyah.

Badan Pusat Statistik. (2018), Perempuan dan Laki-laki di Indonesia. Jakarta: Badan Pusat Statistik.

Buseri, Kamrani. (2015, Desember). Islam Wasâthiyah dalam Perspektif Pendidikan. Makalah yang Dipresentasikan pada Rakerda/Sarasehan Ulama se-Kalimantan Selatan, Banjarmasin.

Dahlan, Abdul Azis. (1996). Ensiklopedi Hukum Islam, Jakarta: Penerbit PT. Ichtiar Baru van Hoeve.

Dery, Tamyiez. (2002). Keadilan dalam Islam. Jurnal Mimbar, 18(3), 337-352.

Eriyanto. (2015). Analisis Isi: Pengantar Metodologi Untuk Penelitian Ilmu Komunikasi Dan Ilmu-Ilmu Sosial Lainnya. Jakarta: Prenadamedia Grup.

Fahriana, Ava Swastika. (2018). Pengambilan Keputusan Secara Musyawarah dalam Manajemen Pendidikan Islam: (Kajian Tematik Al-Qur'an dan Hadist). Al-Hayat, 2(1). 17-46.

Fikri. (2016). Transformasi Nilai Al-Islah Terhadap Keberagaman Konflik: Epistemologi Hukum Islam Dalam Al-Qur'ân. Ar-Risalah, 16(2), 201-216.

Hamka. (2018). Islam Revolusi dan Ideologi. Jakarta: Gema Insani.

-----. (2017). Akhlaqul Karimah, Jakarta: Gema Insani.

Hanafi, Muhammad (2013), Kedudukan Musyawarah dan Demokrasi di Indonesia di Indonesia, Jurnal Cita Hukum, 227-246.

Hude, Muhammad Darwis. (2018). Mengemas Pendidikan Agama Islam yang Bermakna. Qiro'ah, 1(1), 25-43.

Ibnu 'Asyur, Muhammad at-Thahir. (1984). At-Tahrîr Wa al-Tanwir, Juz 2. Tunis: Dar Tunisiyyah.

Ibnu Katsir, Abi Fida Ismail bin Umar. (1974). Tafsîr al-Qur'ân al-Adhîm. Beirut: Dâr Ibnu Hazm.

Ibnu Manzhur. (.th.). Lisân al- 'Arab. Kairo: Dâr al-Ma'arif.

Ibnu Muhammad, Habib Umar. (2013). Wa lâ Tanâza'û Fatafsyalû Wa Tadzhaba Rîhukum. Hadramaut: Markaz An Nur.

Mahallî, Jalâluddîn \& Jalâluddîn al-Suyûthî.(t.th.). Tafsîr al-Jalalain. Beirut: Dâr al-Ma'rifah. Maya, Rahendra. (2017). Pemikiran Pendidikan Muhammad Quthb Tentang Metode Keteladanan (Al-Tarbiyah Bi Al-Qudwah). Jurnal Edukasi Islami, 6(11), 1-16. 
Mazrieva, Eva. (2018, April). Temuan BIN 39\% Mahasiswa Terpapar Radikalisme, Dinilai Harus Ditanggapi Serius . Diperoleh dari https://www.voaindonesia.com/a/temuanbin-39-mahasiswa-terpapar-radikalisme-dinilai-harus-ditanggapi-serius-/4370366.html.

Muhyiddin. (2018, Mei). Grand Syekh Al-Azhar: Wasatiyah Konsep Dasar Islam. Diperoleh dari https://republika.co.id/berita/dunia-islam/islam-nusantara/18/05/01/p81nmp348grand-syekh-al-azhar-wasatiyah-konsep-dasar-islam

Mukhid. (2016). Musyawarah Dalam Perspektif Ekonomi Islam. Jurnal Masharif al-Syariah, $\mathrm{I}(2), 15-27$.

Munawwir. A.W. (1997). Kamus al-Munawwir Arab-Indonesia Terlengkap, Surabaya: Pustaka Progresif 1997.

Muthahhari, Murtadha. (1995). Keadilan Ilahi: Azas Pandangan Dunia Islam, Bandung: Mizan.

Nuh, Muhammad. (2014). Islam, Nilai Sosial, Sikap Keberagamaan Di Tengah Problem Kebangsaan. Politika, 5(2), 1-5.

Qaradhawi, Yususf. (2009). Fatwa-Fatwa Kontemporer, jilid 2. (Terjemahan As'ad Yasin). Jakarta: Gema Insani.

Qutb, Sayyid. (2000). Fî Dhilâli Al-Qur'ân. Juz 1. Beirut: Dar Asy-Syauq.

Rahmawaty, Laily. (2018, Mei). Menggaungkan Islam Wasathiyah dari Indonesia. Dipe- roleh dari https://megapolitan.antaranews.com/berita/39506/menggaungkan-islamwasathiyah-dari-indonesia.

Rangkuti, Afifa.(2017). Konsep Keadilan Dalam Perspektif Islam. Tazkiya, 6(1), 1-21.

Rasyid, Sulaiman. (2018). Fiqh Islam. Bandung: Sinar Baru Algesindo Offset, 2018.

Rozie, Fachrur. (2017, Juli). Radikalisme Ancaman Nyata Pemuda Tanah Air diperoleh dari https://www.liputan6.com/news/read/3034980/radikalisme-ancaman-nyata-pemudatanah-air.

Sastradiharja, Edy Junaedy (2011). Penerapan Konsep Al-Wasathiyyah Dalam Menjaga Kerukunan Hidup di Tengah Pluralitas Masyarakat Indonesia. Makalah pada Pasca Sarjana (S3) PTIQ Jakarta.

Shihab, M. Quraisy. 2019. Wasathiyyah Wawasan Islam tentang Moderasi Beragama,.Tangerang: Lentera Hati 1996. Wawasan Islam. Bandung: Mizan.

Shunhaji, Akhmad. (2017). Kecerdasan Networking Dalam Dakwah Islam, Mumtäz. 1 (2), 109-117.

Sirjani, Raghib. (2015). Solidaritas Islam Untuk Dunia, Terjemahan Ali Nurdin. Jakarta: Pustaka Al- Kautsar.

Sudibjo. (1991). Toleransi Beragama Ensiklopedi Nasional Indonesia. Jakarta: Cipta Adi Pustaka.

Surasman, Otong. (2020). Membangun Pendidikan Keluarga di atas Pundi-Pundi Rabbaniyah. Andragogi, 2(1), 97-124.

Sya'râwî, Muhammad Mutawalli. (1991). Tafsir Asy-Sya'râwî, Jilid 1. Kairo:Akhbâr al Yaum.

Tim Lajnah Pentashihan Mushaf Al-Qur'an.(2010) Tafsir Al-Qur'an Tematik: Pendidikan Pembangunan Karakter Dan Pembangunan Sumberdaya Manusia, Jakarta: Kemenag RI.

Tim Ulama Tafsir Arab Saudi. (2009). Tafsir Al-Muyassar. Saudi: Majmu'Al-Malik Fahd li Thaba'ati al Mushaf al-Syarif.

Usman, Abd. Malik. (2015). Islam Rahmah dan Wasathiyah (Paradigma Keberislaman Inklusif, Toleran dan Damai). Humanika, 15(1), 1-12.

Zuhaili, Wahbah. (2001). al-Tafsîr al-Wasith. Damaskus: Dâr al-Fikr 